\title{
湿式粉砕におけるアルミナボールからの摩耗粉の特性と加熱過程での相変態
}

\author{
吉澤友一・齋藤文良 \\ 東北大学素材工学研究所, 980-77 仙台市青葉区片平 2-1-1
}

\section{Characterization of Abrasion Powder Worn from Alumina Balls by Wet Milling and Its Phase Transformation during Heating}

\author{
Yu-ichi YOSHIZAWA and Fumio SAITO \\ Institute for Advanced Materials Processing, Tohoku University, 2-1-1, Katahira, Aoba-ku, Sendai-shi 980-77
}

\begin{abstract}
Abrasion test of high and low purity alumina balls is conducted in different types of mills under wet condition. The abrasion powder produced by abrasion of high purity alumina balls gave extremely large value of specific surface area over $30 \mathrm{~m}^{2} / \mathrm{g}$. The powder includes $\alpha-\mathrm{Al}(\mathrm{OH})_{3}$ of gibbsite type, while $\alpha-\mathrm{Al}(\mathrm{OH})_{3}$ is not included in an abrasion powder worn from the low purity alumina one. A considerable amount of amorphous aluminum hydroxide is contained in both abrasion powders. The amount of aluminum hydroxide in the powder increased as the milling becomes moderate and as the balls' size is small. The aluminum hydroxide in the abrasion powder is transformed into a single phase of $\alpha$-alumina without forming $\kappa$-and $\theta$-alumina phases at a relatively low temperature of about $900^{\circ} \mathrm{C}$. This is completely different from the phase transformation of an ordinary powder of $\alpha-\mathrm{Al}(\mathrm{OH})_{3}$. The formation of $\alpha$-alumina from abrasion powder at such low temperature is attributed to a seed-effect of fine $\alpha$-alumina powder mixed uniformly in the abrasion powder. An abrasion powder worn in alcohol also enables us to sinter at comparatively low temperature.
\end{abstract}

[Received February 13, 1996; Accepted May 15, 1996]

Key-words : Alumina, Wet ball milling, Abrasion, Aluminum hydroxide, Amorphous, Transformation, Sintering

\section{1. 緒 言}

セラミックスの製造プロセスにおいては，原料の粉砕や混合 を目的としてボールを粉砕媒体とする各種ミル（これを総称し て以下，単にボールミルと称する）が多く使用されている。 た，液相法等により製造されるファインセラミックス原料粉末 やその仮焼粉末の解砕や混合においてもボールミルが使用され る場合が多(1),2). 近年のセラミックスの高性能化のニーズに 対応して, 粉砕に対してもよりファインなサイズ領域への要望 が高まっており，これに対応するためにほとんどが湿式で行な われ，使用される媒体ボールも小径化の傾向にある3 ${ }^{3)}$.一方， ボールミルによる粉砕に拉いては, ボールやミル本体からの摩 耗粉の混入は避けることができない宿命にある11,2)。従来，粉 砕という観点から摩耗粉の生成に関して検討した例は, 幾つか なされている2) 4). しかし，これらの研究例は，粉砕時の摩 耗粉の生成量の把握と生成条件, 摩耗粉混入粉体の特性評価, ないしは, 摩耗粉混入に対する対策が主な課題であり, 摩耗粉 そのものの特性についての検討例は少ない.

本研究では, 粉砕媒体として広く使用されているアルミナに 注目し, 湿式ボールミル法によるアルミナボールの空擦り摩耗 粉を作製し, 摩耗粉そのものの特性とその加熱過程での相変態 挙動について検討した。

\section{2. 実験方法}

摩耗粉の作製には, 振動ミル, 遊星ミル, 転動ミルを用い, 蒸留水を媒液とする湿式法により行った. 振動ミルに扮ける粉 砕ポットには，エンジニアリングプラスチックス製（ナイロン 樹脂）の内径 $80 \mathrm{~mm}$, 容積 $500 \mathrm{~cm}^{3}$ の容器を使用した. ポット に蒸留水とともにボール径 $3,5,10 \mathrm{~mm}$ のボール，それぞれ $1000 \mathrm{~g}$ をミル内容積の80 90\%になるように挿入した。使用 したボールの材質は，アルミナ純度 $99.9 \%$ (高純度) と $93 \%$ (低 純度）である. 粉砕実験は，振動数 $1650 \mathrm{rpm}$, 総振幅 $9 \mathrm{~mm}$ とし，粉砕時間は，48h とした。一方，転動ミルによる粉砕
は，振動ミルと同一のポット及びボール装填率とし，回転速度 は，臨界回転数の78\%となるようにし，480h まで継続運転し た。遊星ミルによる粉砕では，内径 $40 \mathrm{~mm}$, 容積 $50 \mathrm{~cm}^{3}$, 純 度 $99.9 \%$ のルミナ製の容器に $5 \mathrm{~mm}$ もしくは $15 \mathrm{~mm}$ のボー ルを約 $70 \mathrm{~g}$ 装填し，公転数 $710 \mathrm{rpm}$ で $8 \mathrm{~h}$ 継続運転した。表 1 には，これら 3 種類のミルによる粉砕条件をまとめて示す. 表中には，以降の図中に記す略記号も示した。なお，略記号 VA5 は, 対比試験としてアルコールを溶媒としたものである.

得られた摩耗粉は，X 線回折（XRD）による構成相の同定， 熱重量変化（TG）と示差熱分析（DTA）, BET 多点法による 比表面積測定により評価した。熱分析は，アルミナを標準試料 とし，標準，測定試料とも $20 \pm 0.5 \mathrm{mg}$ を使用して室温から $1400^{\circ} \mathrm{C}$ まで $20^{\circ} \mathrm{C} / \mathrm{min}$ の昇温速度で測定した．加熱による構成 相の変化を調べるため，試料を入れたアルミナ製のるつぼを電 気炉に装填し，昇温速度 $5^{\circ} \mathrm{C} / \mathrm{min}$ で昇温し， $2 \mathrm{~h}$ 所定温度で保 持の後, 炉冷した。一部の試料については, 摩耗粉を熱処理の 後にプレス成形し，熱処理と同じ条件で焼結試験を行った。焼 結体の密度は，水を使用した Archimedes 法により測定した。

Table 1. Milling Conditions and Abrasion Loss of Balls Caused by Wear during Milling

\begin{tabular}{ccccccc}
\hline Mill & $\begin{array}{c}\text { Ball diameter } \\
\text { / } \mathrm{mm}\end{array}$ & \multicolumn{2}{c}{ Ball purity Symbol } & $\begin{array}{l}\text { Milling } \\
\text { speed / } \mathrm{rpm}\end{array}$ & $\begin{array}{c}\text { Milling } \\
\text { time } / \mathrm{h}\end{array}$ & $\begin{array}{c}\text { Abrasive loss of } \\
\text { balls / mass\% }\end{array}$ \\
\hline Tumbling & 5 & 99.9 & T5 & 120 & 480 & 1.3 \\
& & & & & & \\
Vibration & 3 & 99.9 & V3 & 1650 & 48 & 2.8 \\
& 5 & 99.9 & V5 & & 48 & 3.8 \\
& 10 & 99.9 & V10 & & 48 & 3.1 \\
& 5 & 93 & VL5 & & 48 & 6.8 \\
& 5 & 99.9 & VA5 & & 48 & 2.2 \\
Planetary & 15 & 99.9 & P15 & 710 & 8 & 2.0 \\
& 5 & 99.9 & P5 & & 8 & 12.3 \\
\hline
\end{tabular}




\section{3. 実験結果}

図 1 に振動ミルを使用し，低純度（アルミナ純度 $93 \%$ ）と 高純度（アルミナ純度 $99.9 \%$ ）のアルミナボール $5 \mathrm{~mm} \phi$ から 作製した摩耗粉の乾燥粉末のXRD 図形を示す。低純度了ルミ ナの摩耗粉（VL5）の XRD パターンは, 若干バックグランド が高いものの明瞭な $\alpha$ アルミナの回折ピークである5). 一方, 高純度アルミナの摩耗粉（V5）の XRD パターンでは, $\alpha ア ル$ ミナのピークのほかに G で示すピーク，すなわち，ギブサイ 卜型の水酸化アルミニウム $\left(\alpha-\mathrm{Al}(\mathrm{OH})_{3}\right)$ が確認される ${ }^{6)}$.

図 2 は, 転動, 振動, 遊星ミルを用い $5 \mathrm{~mm} \phi$ のボールから 作製した摩耗粉のXRD 図形である. 同図には, 粒径が約 0.5 $\mu \mathrm{m}$ の市販の $\alpha$ アルミナと $0.6 \mu \mathrm{m}$ の水酸化アルミニウムを混 合した標準試料（水酸化アルミニウムが 20 及び50 mass\%）の 回折図形も示す. 同図より, まず, 2 種類の標準試料に比べて 摩耗粉の回折図形の回折ピークは, ブロードであり, 半值幅も 広く, 結晶子がかなり小さいことを示している. なた, 回折 ピークの存在しない角度でのバックグランドもかなり高い。一 方, 転動, 振動, 遊星ミルによる摩耗粉を相互に比較すると $\alpha$ アルミナと水酸化アルミニウムからの反射の強度比が粉砕機 毎に若干異なっている.

表 2 には, 摩耗粉の TG 測定において, 室温から $1000^{\circ} \mathrm{C}$ ま での重量減少割合，ならびに，この重量減少すべてがアルミナ の 3 水和物の脱水によるものと仮定した場合の水酸化物の割 合々, 図 2 に示す 2 種類の標準試料の回折図形中の水酸化ア ルミニウムの002反射と $\alpha$ アルミナの01.2反射の積分強度比を 用いて検量線を作成し, 各試料の XRD 図形から求めた強度比 より推定した水酸化アルミニウムの割合を示す．同表より， $\mathrm{XRD}$ のデータより見積もった水酸化物の生成割合は，転動ミ ルの場合が最も多く, 次いで振動ミル, 遊星ミルの順番に小さ くなっている．屯た，同一ミルでボール径の影響を見ると，

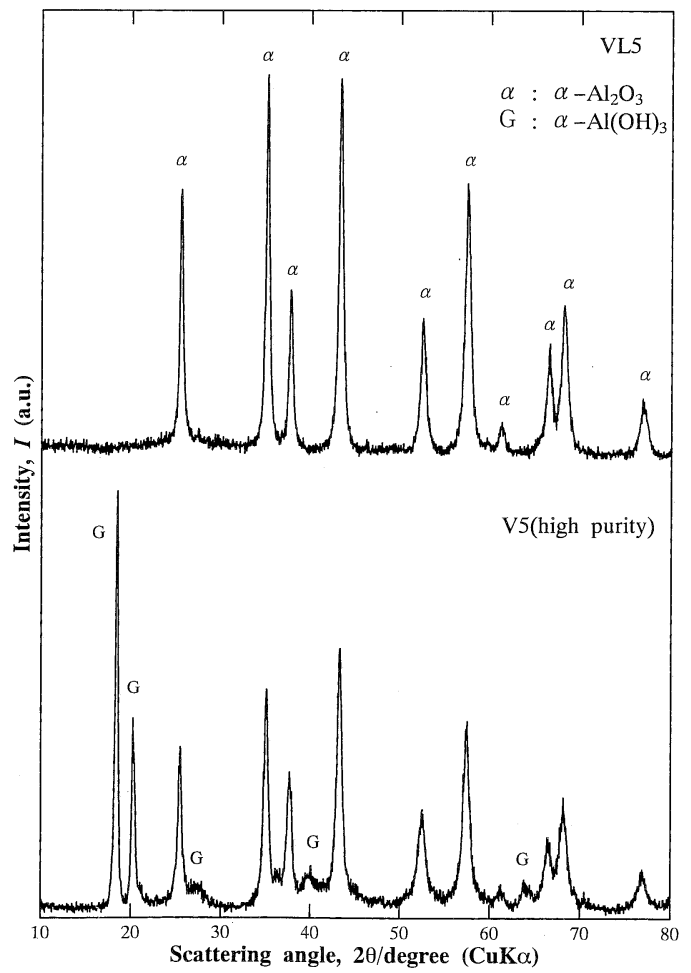

Fig. 1. X-ray diffraction patterns of low purity (upper) and high purity (lower) alumina ball abrasion powders using vibration mill with water.

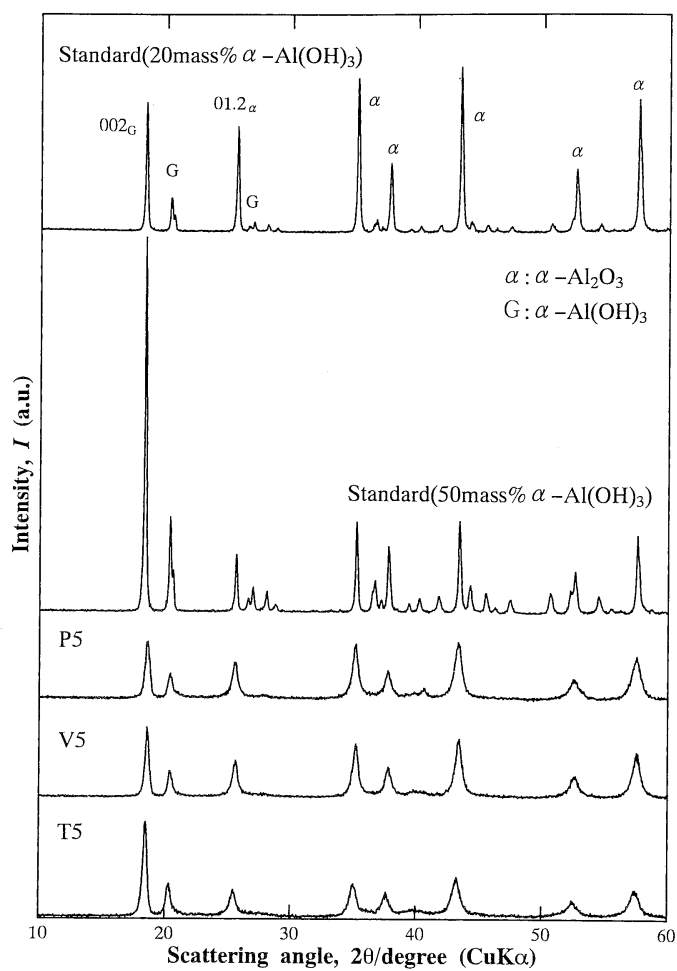

Fig. 2. X-ray diffraction patterns of $\alpha-\mathrm{Al}_{2} \mathrm{O}_{3}$ and $\alpha-\mathrm{Al}(\mathrm{OH})_{3}$ mixture standards and high purity alumina ball abrasion powders using tumbling, vibration and planetary mill with water.

Table 2. Ignition Loss of Abrasion Powders, and Content of $\alpha$ $\mathrm{Al}(\mathrm{OH})_{3}$ Estimated from Ignition Loss and XRD Data

\begin{tabular}{cccc}
\hline Material & $\begin{array}{c}\text { Ignition loss } \\
\text { / mass\% }\end{array}$ & \multicolumn{2}{c}{$\alpha-\mathrm{Al}(\mathrm{OH})_{3}$ content / mass\% } \\
(Ignition loss) & (XRD data) \\
\hline T5 & 20.9 & 60.4 & 27.6 \\
& & & \\
V3 & 17.0 & 49.1 & 23.5 \\
V5 & 11.7 & 33.8 & 23.4 \\
V10 & 9.9 & 28.6 & 18.6 \\
VL5 & 5.3 & 15.3 & 0 \\
& & & \\
P15 & 7.0 & 20.2 & 15.7 \\
P5 & 10.9 & 31.5 & 17.2 \\
\hline
\end{tabular}

ボール径が小さい方が生成割合が大きくなっている，一方，強 熱減量より求めた水酸化物の生成割合は, XRD のデータより 求めたものと同様の傾向を示すものの, その絶対値は，2 倍程 度多くなっている. 特に, 転動ミルのように水酸化物の生成割 合が多いものほど絶対值の差は大きくなっている。 また， XRD では, 水酸化アルミニウムの回折ピークが全く観察され ない低純度アルミナの摩耗粉においても, 強熱減量から推定さ れる水酸化アルミニウムの含有量は，15 mass\%を超えてい る.

図 3 に振動ミルを用い, 低純度アルミナ, 高純度アルミナか らの摩耗粉及び市販の微粒ギブサイト型水酸化アルミニウムの TG-DTA 曲線を示す。同図より，低純度アルミナの摩耗粉で は，加熱による重量減少は約 5\%となる。市た，この重量減少 は，ギブサイト型水酸化アルミニウムのように特定の温度で急 激に起きるものではなく, 室温から加熱とともに徐々に進行し ている.この重量減少の終了温度は, 市販水酸化アルミニウム のそれとほぼ一致する，低純度アルミナの DTA 曲線に注目す ると, $335^{\circ} \mathrm{C}$ 市販の水酸化アルミニウムでは観察されない発 
熱ピークが見られる，一方，高純度アルミナの摩耗粉の熱重量 変化は，全体の重量減量が少ないことを除けば，ほぼ，水酸化 アルミニウムの減量曲線と同じであるが，DTA曲線には，低 純度アルミナの摩耗粉で見られた $335^{\circ} \mathrm{C} に$ 明瞭な発熱ピークが

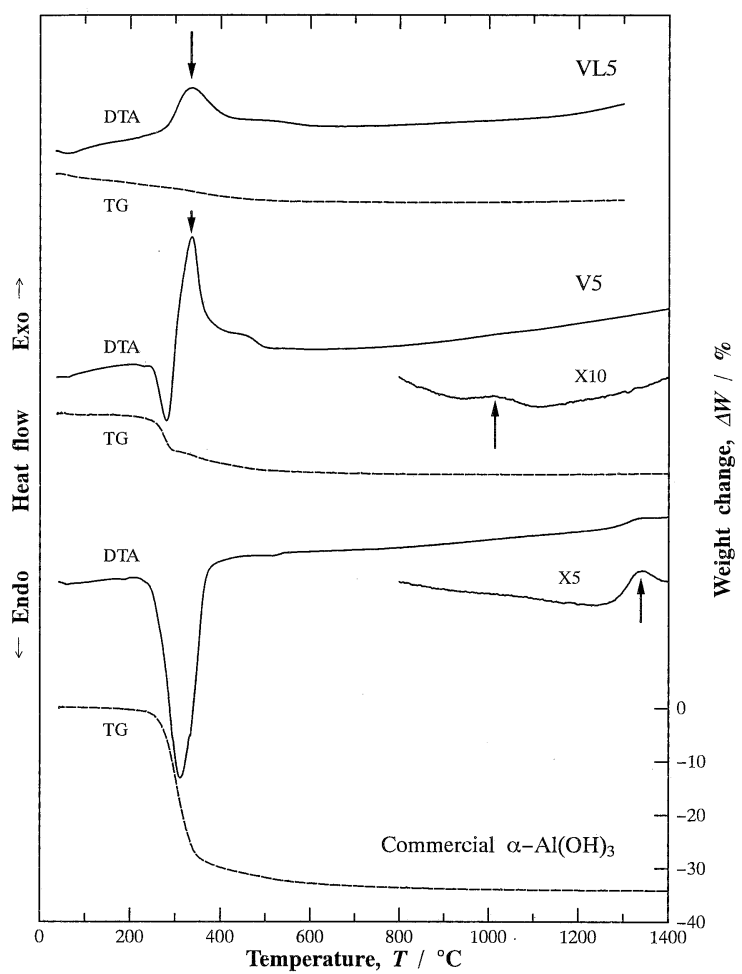

Fig. 3. TG-DTA curves of low purity (upper) and high purity (middle) alumina ball abrasion powders using vibration mill with water, and commercial fine-grained $\alpha-\mathrm{Al}(\mathrm{OH})_{3}$.

\section{観察される.}

図 3 の高純度アルミナの摩耗粉 と市販水酸化アルミニウム の DTA 曲線下部に示す曲線は, DTA 曲線の高温部分の拡大 図（それぞれ10倍と 5 倍）である。市販の水酸化アルミニウ ムでは, 約 $1340^{\circ} \mathrm{C} に$, また, 高純度アルミナの摩耗粉では, $1010^{\circ} \mathrm{C} に そ れ そ ゙ れ$ 発熱ピークが観察される．この高温での発 熱ピークは，アルミナの $\alpha$ 化に対応するものと考えられ $ろ^{7) \sim 9)}$.これより, 湿式粉砕により作製した高純度アルミナ の摩耗粉中に含まれる水酸化アルミニウムは, 通常の水酸化ア ルミニウムに比較して $300^{\circ} \mathrm{C}$ 以上低温で $\alpha$ アルミナ化するもの と予想される.

図 4 には，(a)市販の微粒ギブサイト型水酸化アルミニウム と（b) 振動ミルにより作製した摩耗粉の加熱過程における $\mathrm{XRD}$ パターンを示す．同図より，市販の水酸化アルミニウム は，加熱によりまず り๙アルミナ単相となり， $1200^{\circ} \mathrm{C}$ では，ほとんどが $\alpha$ アルミ ナとなるが，図中に矢印で示すように $\kappa$ アルミナがわずかに 残存する ${ }^{10), 11)}$. この 熱に㧍いても確認された。すなわち，市販の水酸化アルミニウ ムを加熱により $\alpha$ アルミナ単相とするためには, $1300^{\circ} \mathrm{C}$ 上 の加熱が必要であることを意味する。一方，同図(b)に示す摩 耗粉では, $650^{\circ} \mathrm{C} て ゙$ 加熱した試料において $\gamma$ アルミナと思われ るブロードな回折ピークが観察されるものの，他は $\alpha$ アルミ ナからの回折線のみであり, $800^{\circ} \mathrm{C}$ に加熱すると, $\gamma$ アルミナ の回折強度が減少し， $\alpha$ アルミナの回折線が強くなる12)。 $900^{\circ} \mathrm{C}$ 加熱では， $\gamma$ アルミナの回折線は消失し， $\alpha$ アルミナ のみの回折線となる.図中では，散乱角 $2 \theta$ が $41.7^{\circ}, 46.2^{\circ}$ に存 在する $\alpha$ アルミナの00.6, 20.2反射は, JCPDS カードに報告さ れている相対強度が 1 と非常に弱い反射であるが， $900^{\circ} \mathrm{C}$ で焼 成した試料の回折図形では明瞭に認められる5)。このことは, $900^{\circ} \mathrm{C}$ の焼成でほとんど $\alpha$ 化が終了していることを示してい

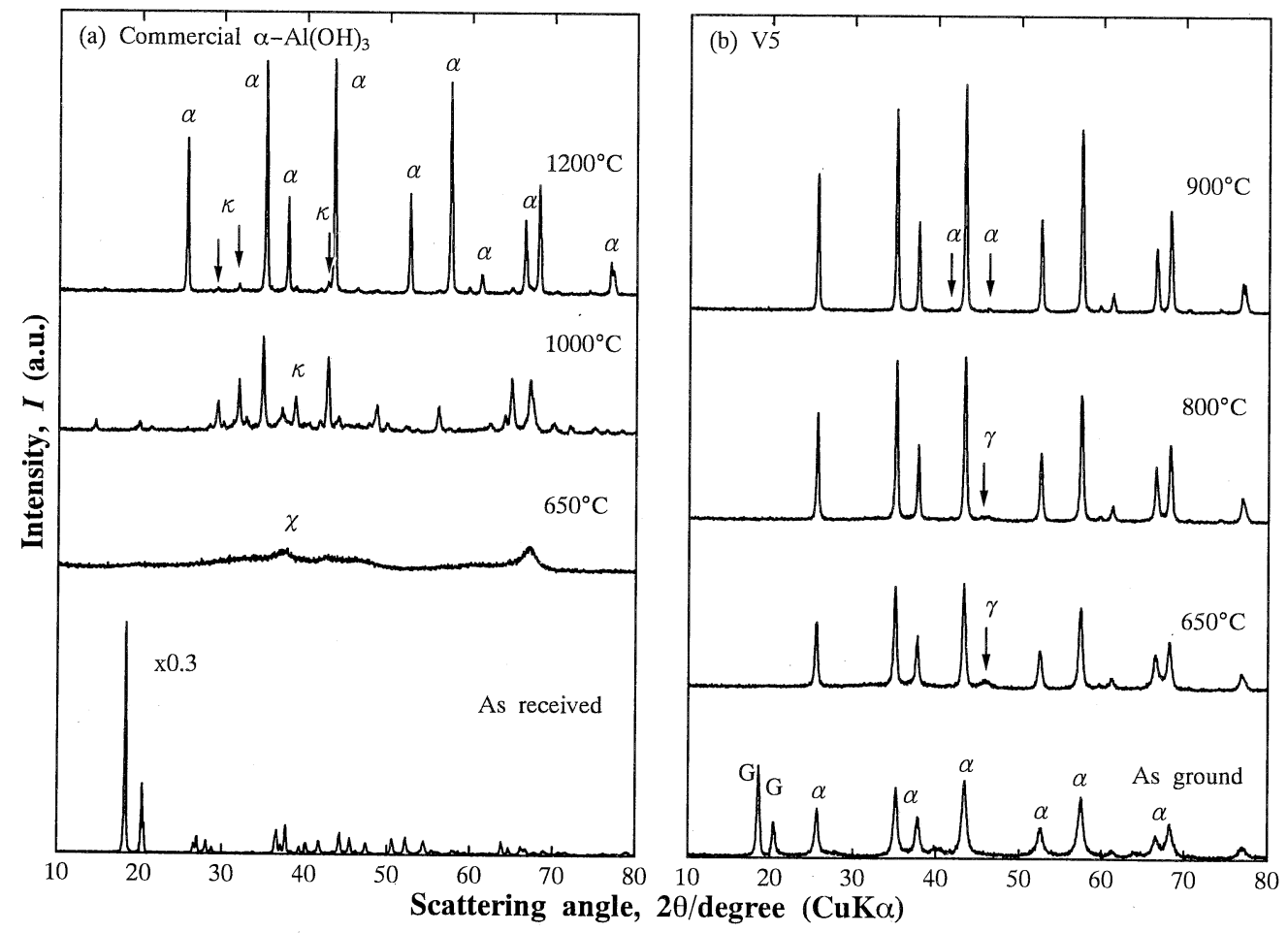

Fig. 4. X-ray diffraction patterns of (a) commercial fine-grained $\alpha-\mathrm{Al}(\mathrm{OH})_{3}$ and (b) high purity alumina ball abrasion powders heated at various temperatures. 
Table 3. Specific Surface Area (SSA) and its Equivalent Diameter of Heated Abrasion Powders

\begin{tabular}{lccc}
\hline Material & $\begin{array}{c}\text { Heat temperature } \\
/{ }^{\circ} \mathrm{C}\end{array}$ & $\begin{array}{l}\text { Specific surface } \\
\text { area } / \mathrm{m}^{2} / \mathrm{g}\end{array}$ & $\begin{array}{l}\text { Equivalent diameter } \\
\text { of SSA } / \mathrm{nm}\end{array}$ \\
\hline VA5 & 650 & 49.6 & 30.4 \\
V5 & 800 & 28.3 & 53.5 \\
& 900 & 17.7 & 85.2 \\
& 1000 & 14.7 & 103 \\
P5 & (As-ground) & 45.0 & \\
P15 & (As-ground) & 31.3 & \\
$\alpha-\mathrm{Al}(\mathrm{OH})_{3}{ }^{*}$ & 1300 & 7.3 & 210 \\
& 1400 & 4.4 & 340 \\
Alumina A & (As-received) & 5.0 & 300 \\
Alumina B & (As-received) & 14.5 & 104 \\
\hline * Commercial fine-grained $\alpha-\mathrm{Al}(\mathrm{OH})_{3}$ (Gibbsite type)
\end{tabular}

Table 4. Relative Density of Sintered Abrasion Powders and Commercial High-Purity Alumina Powders

(\%TD)

\begin{tabular}{lccccc}
\hline \multirow{2}{*}{ Material } & \multicolumn{5}{c}{ Sintering temperature $/{ }^{\circ} \mathrm{C}$} \\
& 1250 & 1300 & 1350 & 1400 & 1500 \\
\hline VA5 650 & & & \\
& & & \\
& & $2 h$ \\
V5 $900^{\circ} \mathrm{C} 2 \mathrm{~h}$ & 96.0 & 98.5 & 99.5 & & \\
VL5 650 & 98.6 & 99.2 & 100.0 & & \\
Alumina A & & 92.8 & & 94.5 & 93.8 \\
Alumina B & & & & 96.6 & 99.8 \\
\hline
\end{tabular}

る.

表 3 は, 摩耗粉と市販粉末の比表面積から形状係数を 6 と し，粉末がすべて $\alpha$ アルミナと仮定して計算される比表面積 径を示す。なお，粉砕の際に樹脂製のポットを使用した場合 （VA5）は，少量の樹脂の摩耗粉が混入し比表面積が過大に測 定されてしまったため, $650^{\circ} \mathrm{C} て ゙$ 樹脂を加熱除去した後の值を 示した．また，遷移アルミナを含むものは，ほぼ， $\alpha$ 化が終了 したと思われる試料の值を示す．同表より，650 Cで加熱した アルコール中での摩耗粉の比表面積は, $50 \mathrm{~m}^{2} / \mathrm{g}$ 程度であり, 非常に細かい粉末であることが分かる. 一方，水中での摩耗粉 を加熱し， $\alpha$ アルミナとした粉末の比表面積は，市販の微粒水 酸化アルミニウムを高温加熱で $\alpha$ アルミナとしたものに比べ て非常に大きな值である，また，市販の焼結用高純度アルミナ と比較しても比表面積は大きく, 比表面積径は，0.1 $\mu \mathrm{m}$ 以下 である。

表 4 には, 摩耗粉を加熱し樹脂を除去, 及び， $\alpha$ アルミナ化 した試料と市販の高純度アルミナ粉末 A, B（純度99.99 99.999\%）を各温度で焼結したときの焼結密度を $\alpha$ アルミナ の理論密度に対する割合で示す. 高純度アルミナボールから作 製した粉末は， $1250^{\circ} \mathrm{C}$ の焼結で相対密度 $96 \%$ 以上， $1300^{\circ} \mathrm{C}$ の 焼結では， $98 \%$ 以上の高密度となる．若干の測定誤差を考慮 すると $1350^{\circ} \mathrm{C}$ 焼結でほぼ理論密度に達している。この值は， 高純度アルミナ（アルミナA）を大きく上回るものであり， 最も焼結性に優れた市販高純度アルミナ（アルミナB）に匹敵 する值である，一方，低純度アルミナボールの摩耗粉の焼結体

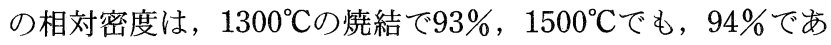
る.

\section{4. 考 察}

\section{1 摩耗粉の特性}

湿式ボールミル法による高純度アルミナボールからの摩耗粉
は，多量の水酸化アルミニウムを含有していることが分かっ た. 本研究と粉碎条件は異なるが，アルミナ粉末の転動ボール ミルによる湿式粉砕において，水酸化アルミニウムの生成が報 告されている33,13). 田中らは， $\alpha$ アルミナ結晶がメカノケミカ ル反応によってギブサイト結晶に転移したと結論し，0.75〜 $30 \mathrm{~mm}$ のボールのうち, ギブサイト結晶の含有量は, ボール 径 $2 \mathrm{~mm}$ で最大值を示すことを報告している3). 本研究の範囲 内では, 摩耗粉中のギブサイト型水酸化アルミニウムの含有率 は，同一ミルでは，ボール径が小さいほど多く既報の結果と一 致する. 特に，遊星ミルによるデータで顥著に見られるように 摩耗粉の量と摩耗粉中の水酸化了ルミニウムの含有率は, ボー ル径が小さい方が多い．ボール充填率一定の下では，ボール径 が大きい方が明らかに 1 個のボールの衝撃力は大きいが，逆 にボール同士の全接触回数は少ない。一方, 本研究で用いた転 動, 振動, 遊星ミルにおけるボールの加速度は, それぞれ, 1G, 13.7G, 83.3G と計算され, したがって, 粉砕機内のボー ルの衝撃エネルギーは, 転動, 振動, 遊星ミルの順番に大き (14),15)。一方, 摩耗粉中の水酸化アルミニウムの含有率は, 転動ミルが最も大きく，エネルギーの大きなミルほぼ小さい。 もちろん, 摩耗粉の生成や $\alpha$ アルミナの水酸化アルミニウム への変化には, ある臨界のエネルギーが必要であると考えられ るが, この臨界值以上の衝撃がある場合には, 衝突頻度の多い 条件の方が摩耗粉の生成や水酸化アルミニウムへの变化が多い と考えられる。

低純度アルミナボールからの摩耗粉は, XRD に扔いては, $\alpha$ アルミナからの回折ピークのみが観察されたが, TG 曲線に おいては加熱減量が認められた.この加熱重量減少挙動は, ギ ブサイト型水酸化アルミニウムを乾式粉砕により無定形化した ものの加熱減量曲線と良く一致する16)。 また, 高純度アルミ ナボールの摩耗粉についても表 2 に示したように強熱減量と $\mathrm{XRD}$ から推定した水酸化物の量に大きな差があることや摩耗 粉の XRD 図形のバックグラウンドが比較的高いことを考える と, アルミナの水中粉砕によって生成する水酸化アルミニウム は, かなりの量の非晶質を含むものと推定される。そして, DTA における $335^{\circ} \mathrm{C} て ゙ の$ 発熱ピークは, 非晶質水酸化アルミ 二ウムが脱水中もしくは脱水後に結晶質の遷移アルミナに変化 したものと考えられる.この非晶質水酸化アルミニウムの含有 率は, 摩耗粉中にギブサイト型水酸化アルミニウムの含有率が 多いものほど大で, 転動ミルで作製した摩耗粉においては, ギ ブサイト型水酸化アルミニウム以上の割合となっている.すな わち, 非晶質水酸化了ルミニウムの生成には, ボール同士の強 い衝撃力よりは, むしろ衝突頻度がより大きく関与しているも のと考えられる.

低純度ボールの摩耗粉において，ギブサイト型が見られず非 晶質のみが認められた原因としては, 低純度ボール摩耗粉の平 均粒子径が数 $\mu \mathrm{m}$ と高純度ボールの摩耗粉に比較して 100 倍程 度大きいことや, 摩耗粉中の水酸化物の含有率が低いこと, も しくは, 焼結助剤として添加された粒界ガラス相の影響等が考 えられるが, 現時点では明らかではない。

\section{2 摩耗粉の加熱過程での構成相の変化}

本研究で作製した高純度アルミナボールからの摩耗粉は, 最 大で $60 \%$ もの水酸化アルミニウムを含み, この水酸化アルミ ニウムの加熱過程での相変化は, 通常の水酸化アルミニウムと 大きく異なっている。すなわち, 市販のギブサイト型水酸化ア

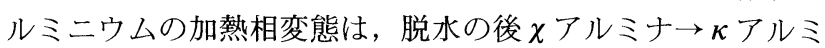

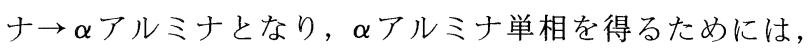
$1300^{\circ} \mathrm{C}$ 超える加熱温度が必要である. これに対して, 本法 
によって得られる摩耗粉では, $800^{\circ} \mathrm{C}$ 以下の加熱によっても $\alpha$ アルミナ量の増加が認められ, $900^{\circ} \mathrm{C} の$ 低温加熱で $\alpha$ 化が完了 する. 本研究で作製した摩耗粉は, 少ないものであっても $40 \%$ 程度の $\alpha$ アルミナを含んで抢り，このことは，水酸化ア ルミニウムに $\alpha$ アルミナの種を多量に添加したものと考える ことができる. Kumagai と Messing は, ゾル-ゲル法によるア ルミナの製造に拈いて $\alpha$ アルミナの種の効果を検討し, 種の 粒子径が小さい方が効果が大きく, また, 添加量が多い方が $\alpha$ 化温度が低下することを報告している17)。このことを考慮す ると本法により作製した摩耗粉の粒子径は, 従来の報告で使用 された種としての $\alpha$ アルミた比較して極めて小さいため, 種の効果がより顕著に現れたものと考えられる. また， $\kappa$ 相や $\theta$ 相が出現しない理由は, 安定相である $\alpha$ アルミナが多量かつ 均一微細に混合されたためであると思われる。

さて, 本研究で作製した摩耗粉には, 前述のとおり最大で $30 \%$ 程度の非晶質水酸化アルミニウムを含むため，これが $\alpha$ 化に影響を及ぼしていることも考えられる. Sugiyama らは, ギブサイトを乾式粉砕により無定形化したものは，DTAによ る高温での発熱ピークが約 $1000^{\circ} \mathrm{C} に$ 低下することを報告して おり，無定形化したことによって容易に $\alpha$ アルミナ化すると 結論している16)。しかし, Sugiyama らが使用した転動ボール ミルのポット, ボールは, いずれもアルミナ製であり, 粉砕産 物中に $\alpha$ アルミナ摩耗粉が混入したことも考えられる。一方, Tonejc らは，超硬合金のポットとボールを使用した乾式粉砕 において室温の粉砕のみでギブサイト型水酸化アルミニウムか ら $\alpha$ アルミナが生成することを報告している18)。この事実は， Sugiyama らの実験においても乾式粉砕中に少量の $\alpha$ アルミナ が生成した可能性を示唆する. 以上の考察より, 本研究で作製 した摩耗粉が極めて低温で $\alpha$ アルミナ単相となったのは, 粉 砕中に均一に混合された微細な $\alpha$ アルミナの種の効果と結論 される。また，摩耗粉が低温度で $\alpha$ アルミナ化できるため, 生成する $\alpha$ アルミナ粒子が微細であり，市販の高純度アルミ ナ粉末に比較して, 本研究で使用した高純度アルミナボールの 純度が低いにもかかわらず，良好な焼結性を示す結果になった ものと考えられる。

\section{5. 結 論}

湿式粉砕における高純度及び低純度アルミナボールからの摩 耗粉の生成とその特性評価に関する実験的検討結果を要約する
と以下のとおりである。

（1）高純度アルミナボールを用いた場合の摩耗粉は，比表 面積 $30 \mathrm{~m}^{2} / \mathrm{g}$ 以上となり，きわめて微細な粉末が得られる.

(2) 高純度アルミナボールからの摩耗粉は，かなりの量が ギブサイト型 $\alpha-\mathrm{Al}(\mathrm{OH})_{3}$ になるが低純度アルミナボールを用 いた場合の摩耗粉は, $\alpha-\mathrm{Al}(\mathrm{OH})_{3}$ にならない。しかし, 両者 ともかなりの量の非晶質水酸化アルミニウムを含む.

（3）摩耗粉中の水酸化物の含有率は，粉砕条件により異な り, ボール径が小さいほど, また, ミルの粉砕エネルギーが小 さいほど多い。

（4）摩耗粉に含まれる水酸化アルミニウムは, 通常の $\alpha$ $\mathrm{Al}(\mathrm{OH})_{3}$ と相変態経路が異なり, $\kappa$ 相や $\theta$ 相が出現せず, 約 $900^{\circ} \mathrm{C}$ の低温加熱で $\alpha$ アルミナ単相となる。これは, 均一に混 合された微細な $\alpha$ アルミナの種としての効果と考えられる.

（5）水中での摩耗粉ばかりでなくアルコール中でのそれも 比較的低温で焼結可能である.

\section{文献}

1) 柳沢雅明, 椿 淳一郎, 粉体工学会誌, 27, 634-38 (1990).

2) 桑原好孝, 淡野正信, セラミックス, 31, 35-38 (1996).

3) 田中謙次, 稲田 勇, 脇野喜久男, 上井 勲, 37, 1319-25 (1988).

4) T. Yokoyama, K. Tamura and G. Jimbo, "Proc. Trilateral Symposium on Particuology”, Ed. by G. Jimbo, J. K. Beddow and M. Kwauk, Science Press (1988) pp. 178-83.

5) JCPDS card, No.42-1468.

6) JCPDS card, No.33-18.

7）坂本憲一, 窯協, 64, 40-51 (1959).

8）若尾芳之, 日比野泰三, 名古屋工業技術試験所報告, 11, 588-95 (1962)

9) S. Rajendran, J. Mater. Sci., 29, 5664-72 (1994).

10) JCPDS card, No.4-0880.

11) JCPDS card, No.4-0878.

12) JCPDS card, No.10-425.

13）近藤祥人, 橋塚 豊, 中原理栄, 横田耕三, 石㟝幸三, J.Ceram. Soc. Japan, 101, 819-23 (1993).

14）神保元二, セラミックス, 31, 24-29 (1996).

15）横山豊和, 第25回粉体に関する講演討論会論文集, 27-41 (1995).

16) K. Sugiyama, A. H. Shinohara, F. Saito and Y. Waseda, Mineral. J., 17, 101-10 (1994).

17) M. Kumagai and G. L. Messing, J. Am. Ceram. Soc., 68, 50005 (1985).

18) A. Tonejc, M. Stubic̈ar, A. M. Tonejc, K. Kosanović, B. Subotić and I. Smit, J. Mater. Sci. Lett., 13, 519-20 (1994). 